\title{
Value, (use) values, and the ecologies of capital: on social form, meaning, and the contested production of nature
}

\section{Luis Andueza}

This paper connects hitherto distant strands of literature to contribute to the ongoing turn to value theory in socio-ecological studies. Starting from Marx's understanding of value as social form, I revisit Neil Smith's contribution to the question of value and nature and argue for a reassessment of the internal relations between valorisation and the 'vernacular' dimensions of socio-ecological reproduction. I approach this problem through Bolívar Echeverría's reconstruction of the category of use-value and his understanding of the pivotal role it plays in Marx's critique, which allows for an open and non-reductive account of the subsumption of socio-ecologies under capitalism as contradictory entanglements of abstraction and meaning. The paper mobilises these insights alongside Marxian-inspired anthropological theories of value-the work of Terence Turner and David Graeber-in order to sketch elements for a symbolic-materialist framework to approach the question of value in its cultural-moral register, its relation to value as economic form, and issues of moral economy and ecology under capitalism.

Keywords: Marxism, value theory, political ecology, anthropological theories of value, world-ecology, usevalue, nature and society.

\section{Introduction}

What does it mean to think about our relation to nature through the lens of value? This is the question animating the recent and ongoing turn to value theory within critical ecological studies in geography and beyond (e.g. Kay and Kenney-Lazar, 2017; Kenney-Lazar and Kay, 2017; Huber, 2016; Andreucci et al., 2017; Arboleda, 2019; Christophers, 2016; Robertson $¥$ and Wainwright, 2013; Purcell et al., 2019; Kallis and Swyngedouw, 2018; Greco and Apostolopoulou, 2019). And indeed, beyond academic debates, from the rarefied spheres of the world-system's financial centres, to its often-bloody frontiers of extraction, talk of value and worth saturates the fraught geographies of capitalism's socio-ecological reproduction. Whether the variegated and compounding transformations in nature compelled by capital accumulation are productive or destructive, whether they create wealth or inflict misery-all of these controversies constitute a political field in which 
what is ultimately at stake are the forms of value that define the very meaning of these dichotomies; the different and contesting conceptions of the desirable that mediate our relation to nature, and each other. Perhaps the ubiquity of struggles over what value is, especially when we speak of nature, only attest to the cultural depth of the crisis of liberal-capitalist hegemony, as it confronts its catastrophic unfolding as part of natural history (Wainwright and Mann, 2018; Moore, 2015).

In this context, as Kay and Kenney-Lazar (2017) note, the concept of 'value' may hold an enormous potential to be developed as an "organizing framework" for geographical inquiry on the ongoing capitalist organisation, production, and destruction of nature, and on the multiple resistances immanent to these processes. In this sense, recent reengagements with Marx's value theory can only be welcomed-as Huber (2016) notes, relative to the proliferation of empirical studies on the 'valuation of nature', engagements with the theoretical grounds on which the concept is mobilised remain conspicuously rare (cf. Robertson and Wainwright, 2013). While these debates show, at the very least, the generative potential of renewing discussions of Marx's core concept in relation to nature, they also show how the value-nature relation, still far from constituting shared framework of analysis, appears rather as an open field of questions, divergent readings, and disagreements. Among other things, they show widely different understandings of what Marxian value theory is about, of what, if any, ecological significance it holds, and of the nature of the relation between the word's different semantic registers-value as measure, value as economic form-determination, and value as moral-cultural category (e.g. Bigger and Robertson, 2017; Kay and Kenney-Lazar, 2017: 304-306).

In this paper I want to connect hitherto geographically and disciplinarily distant strands of literature in the hope of shedding new light on these and other questions that have recently emerged around the ecological dimensions of Marxian value theory. As is the case with the field of political ecology in general (Loftus, 2017), and value-nature relations in particular (Sullivan, 2017: 312), a broadening of the disciplinary and geographical scope of these debates can infuse much needed new perspectives.

It is worth noting that among the most common criticisms of Marx's value theory to reemerge in these recent discussions is that of anthropocentrism, of how the understanding of value as constituted by abstract human labour renders the theory ill-suited, at best, to understand the role of nature in capitalism (e.g. Walker, 2017; Kallis and Swyngedouw, 2018). Relatedly, other criticisms take aim at the purported 'economistic' nature of Marxian value theory, which would fail 
to account for the importance of the different forms of value and meaning mediating the social relation to nature-values which, in the Marxian framework, would be reduced to the allegedly economistic and utilitarian notion of use-value (e.g. Gudynas, 2019). While these lines of criticism arguably hold for a good deal of 'traditional' readings Marx (see Elbe, 2013; Postone, 1993), in my view they fail to acknowledge the ways in which Marx's value theory fundamentally departed from the classical labour theory of value, and indeed is to be read most productively as a fundamental critique of the "categorical presuppositions" of the entire field of political economy (Heinrich, 2012: 32-36). In other words, to understand the ecological significance of Marx's value theory it is fundamental to read it as critique-one that, far from reaffirming capitalism's anthropocentric and economistic ontology, precisely provides the grounds for its radical materialist critique as an ontology rooted in, and reproduced through, the historically situated social forms that articulate socio-ecological reproduction under the capitalist mode of production.

In this sense, and drawing from different strands of critical readings of Marx ${ }^{1}$, this paper starts from an understanding of Marx's value theory as a radical critique of, on the one hand, the real abstraction of the practical, embodied, and variegated human entanglement with nature into "human labour in the abstract" (Marx, 1990: 128) - or 'labour' as purely generic human activityand, on the other, the concomitant subsumption of socio-ecological reproduction under the compulsions of its own fetishistic inversion in the form of a "phantom-" and "vampire-like" (Marx 1990:128, 342) field of economic objectivity-i.e. capital. And it is on the contradiction-ridden dynamics of this condition that Marxian value theory opens what in my view remains a unique avenue of inquiry: the critique of political economy, of value, as "a social" - and ecological"critique of economic inversion" (Bonefeld, 2018: 123), a critique of the specific social forms-value, money, commodity, profit, wage, etc. - through which the "social life-process" is constituted in the capitalist mode of production, and as an analysis of the contradictions that beset the historical unfolding of this condition. In this sense, far from economistic, Marx's theory provides the grounds for a radical critique of 'economic objectivity' itself as a historically specific social form of socioecological reproduction, characterised by the irreducible contradiction between the qualitative, embodied dimensions of life, and its subsumption under the overbearing demands of its quantitative abstraction as infinitely expanding magnitudes: self-valorising value.

I will start by considering in what way Marx's value theory can be understood as inherently ecological, a question only intermittently developed within critical ecological thought. For this, I will 
go back to what I consider to be the core, yet rarely acknowledged, contribution of Neil Smith's thesis on the "production of nature" to this question: the positing of value as a category of socioecological constitution. Although Smith, against previous Marxian theorisations of nature, correctly understood value as an internal and constitutive moment of what we call nature, as Ekers and Prudham point out $(2017 ; 2018)$, much of Smith's thesis' pitfalls lie in his relative neglect of the crucial theoretical importance of the use-value dimension in Marx's critique. This is, I will argue, what has left Smith's thesis-and much of the tradition of ecological thought it inaugurated-liable to lapse into forms of constructivism that risk ignoring precisely the crucial contradiction at the centre of Marx's theory: that between concrete socio-ecological metabolism and its social form (Saito, 2017; Burkett, 2014). As long noted by critical appraisals of the production of nature thesis (Castree, 1995; Bakker and Bridge, 2006; Braun, 2008; Malm, 2018a), this metabolism presents an irreducible autonomy; an autonomy, I want to argue, that cannot be considered 'external' to the fetishized social forms of capitalist society-i.e. a natural sphere clearly separate from a social one, but rather internally constitutive of the contradictory (and destructive) unfolding of these forms as ecological projects.

It is important to note, however, that most of these reappraisals of the role of use-value tend to gravitate around issues of 'materiality' and non-human nature's recalcitrance. I think this still leaves far too much of the significance of the category of use-value unexplored. This category should not be primarily understood as constituting a simple bio-physical substratum of the social form of value, but, perhaps above all, the cultural substratum of meaning in which concrete labour and everyday practice is always embedded; a dimension with which the abstract process of valorisation must always recon in one way or another for its realisation. In other words, the concrete socio-ecological actualisation of capitalism can only manifest itself as an intricate relation between the processes of abstraction entailed in the constitution and expansion of economic forms and the multiple vernacular human mediations of meaning and practice in which these forms must ultimately find their cultural grounds -in other words, it expresses the ultimate inextricability of value and use-value. Following the late Mexican-Ecuadorian philosopher Bolívar Echeverría, I explore the concept of use-value as signalling the necessary 'horizons of meaning' in which the valorisation of value and human practice must always be contradictorily rooted-a contradictory internal relation that gives rise to the specific cultural forms that mediate socio-ecological reproduction under capitalism, and constitute the cultural grounds for the political composition of both domination and resistance. This in turn leads to a problematisation of the concept of 
'production' itself, when approached from the point of view of use-value. Finally, I will explore the possibility of a symbolic-materialist approach to this field of meaning/value drawing from anthropological theories of value rooted in Marx's, in particular the work of Terence Turner and David Graeber. Through an understanding of value(s) as a semiotic process of mediation between human subjective activity and its sociality, integrated with a revised notion of the production of nature, I aim to sketch out a route to a more textured account of the contested (re)production of the actually existing landscapes of capitalism, hopefully giving value theory much needed ethnographic traction. As Ekers and Loftus (2013) point out, what is needed is linking what remain very abstract theoretical categories to a more textured account of the concrete practical, ecological, and symbolic density of the landscapes in which capital is reproduced and resisted.

\section{Value and Neil Smith's thesis on "the production of nature"}

For Marx, the category of 'value' grasped the core of capitalist modernity in its most essential terms -it designated that which made capitalist domination so historically distinct (Postone, 1993). In its Marxian reading, 'value' ${ }^{2}$ is an historically specific form taken by human material relations of interdependence and mutual constitution-“social life-process" (Marx, 1990:173)-one in which relations between people constitute themselves in the fetishized and self-expanding form of an alien economic objectivity (Bonefeld, 2014). As a theory about a historically specific form taken by the social character of the metabolic relation to nature (i.e. labour) (Marx, 1990:174), Marx's theory of value has always been by implication a theory of the specificity of socio-ecological relations under capitalism.

Formulated in this way, the fact that Marx's theory of value has fundamental ecological implications may seem self-evident. And yet these implications have only been intermittently explored systematically within the Marxist tradition ${ }^{3}$. One of the first to explicitly take this direction was Neil Smith, through his thesis on the 'production of nature' (Smith, [1984] 2008). Smith's contribution was greatly influential, as it inaugurated a distinct branch of Marxist ecological thought, one with particular influence within Geography. In the three decades since its original formulation, much has been written on the merits and pitfalls of Smith's thesis. Reviewing this literature in depth is beyond the scope of this paper. My purpose in going back to Smith is instead to recover his underappreciated, but nonetheless crucial contribution regarding the ecological significance of Marx's value theory, and try to develop this idea in a somewhat different direction, one that can 
avoid some of the crucial weaknesses running through much of this strain of Marxist ecological thought.

Smith considered that the notion of 'Nature' as an external domain, fundamentally independent and clearly distinguishable from human activity, was an ideological form rooted in the particular material experience of the bourgeoisie (2008: 28). This dualist conception of Society and Nature renders the latter in principle independent from social relations and labour. 'Nature', through an historical process of "aggressive externalization" (Smith, 2007: 24), is thus rendered a domain defined as object without subject. This is nothing less than the ontological underpinning of primitive accumulation-i.e. the material separation of humanity from nature, through which the historical conditions for capitalism (the production of a collective subject without object-the proletariat) came about. As such, for Smith the ideological notion of 'Nature' abstracted the central role of labour in what he called 'the production of nature'. Smith, following Marx (1990:283), argued that the labour process is a transformative moment of both its human and non-human elements, and that therefore so-called 'natural conditions' are not only a premise, but also a product of society's metabolic history. Nature is thus produced. The traditional Marxist equation of nature with the realm of use-value is thus for Smith severely misguided. Insofar as the capitalist labour process is subsumed under the imperatives of valorisation, value should be conceptualized as an ecological force in its own right. In Smith's own words:

[I]t is the abstract logic that attaches to the creation and accumulation of social value which determines the relation with nature under capitalism. Thus the movement from the abstract to the concrete $(. .$.$) is the perpetual translation actually achieved in the relation with nature$ under capitalism; abstract determinations at the level of value are continually translated into concrete social activity in the relation with nature. (Smith, 2008:70, emphasis added.)

Within capitalism, 'first nature' - defined by Smith as the concrete effect of the labour process and the realm of use-values-is subordinated to the 'second nature' of the abstract value relation, under the imperative of profit as the ultimate systemic telos. For Smith, due to the "ability of capital to produce the material world in its own image (...) the production of first nature from within and as part of second nature makes the production of nature, not first or second nature in themselves, the dominant reality" (Smith, 2008:83).

Smith thus posits the category of value as one of socio-ecological constitution: under capitalism the material constitution of a growing field of ecological relations is thoroughly implicated 
in the reproduction of value relations - value effectively functions as a constitutive environmentmaking force in the capitalist landscape through the real subsumption of the labour process. Moreover, it can be further said that the capitalist law of value is premised upon a particular set of spatial and environmental relations: i.e. the ongoing enclosure of commons, the separation of people from land, and the concomitant creation of the conditions for the private appropriation of social labour through the wage relation. Rather than merely having environmental 'effects', the emergence and persistence of the capitalist law of value is contingent on the ongoing reproduction of a particular sort of landscape (cf. Moore, 2015).

\section{Abstraction, materiality, and meaning: on the limits of Smith's thesis}

Smith stressed the difference between his conception of production of nature and that of the 'domination of nature' emergent from the Frankfurt School (e.g. Schmidt, [1971] 2014), by signalling the "ways in which social production can create accidental, unintended and even counter-effective results vis-à-vis nature": instead, his thesis "makes no pretence to the control of nature" (Smith, 2007: 24). Yet, the theoretical basis provided by Smith allows for no way of understanding these unruly, yet conspicuous, moments of capitalist ecologies other than as the spasmodic consequence, however unintended, of a logic of valorisation constituted as the central organising principle in nature itself (Smith, 2008:91). This is something Smith's critics picked up early on. For example, Bakker and Bridge (2006), foregrounding the recalcitrance often entailed in non-human nature's materiality, emphasised how the production of nature thesis "struggled with how to represent the active capacities of biophysical processes dialectically without invoking an external nature", and that

"by envisioning first nature transformed via labour, ends up squeezing out any productive or generative role for ecological or biophysical processes" (2006:9; see also Castree 1995, Ekers and Prudham 2017; 2018; and Malm 2018). In a similar vein, Braun (2008) argued that although much of the work carried on in the wake of Smith's thesis did make an effort to reincorporate non-human nature's inherent resistances, it largely failed to do so without ultimately representing this as 'external' to a pre-constituted ontological field of economic forces; a structure of accumulation upon which non-human nature exerted its resistances and imposed its terms 'from the outside' (2008:668-669).

Similar problems have been pointed out regarding how Smith's thesis relates to the complexities and differentiation of concrete human labour. In their reassessment of Smith's thesis 
and the work done in this tradition, Ekers and Loftus (2013) identify "a hiatus between concrete studies that focus on the differentiation of labour, and work that concentrates on the capital-labour relation in the abstract (as socially necessary labour-time)" (2013:243), and, turning to Gramsci's 'historicizing impulse', call for a firmer grounding of theorisation in the concrete and multiple determinations of human practice. Eaton (2011) for her part, draws attention to how agrarian production at once illustrates the force of the production of nature as framework, but also highlights its shortcomings, especially in relation to the multiple mediations organising concrete labour in family farms; and to how the production of nature has to be also approached as the production of meaning, an issue that, although acknowledged by Smith (2008:107), was not developed to the extent the central role of place in the differentiation of nature would demand.

Underlying these critiques and openings is in my view the question of how to adequately understand the relation between economic forms - the "abstract logic" of which Smith considers drives the production of nature "all the way down"-and their concretion in socio-ecological reproduction. Pace Smith, and as these critiques point out, the ecologies produced by the uneven process of subsumption of the latter under the former cannot be adequately reduced to the abstract determinations of valorisation, but instead constitute intricate and fraught entanglements of internally related moments of abstraction, meaning, and materiality-of value and use-value. There is a crucially important dialectical relation of non-identity at play here; one that gets lost in Smith's attempt at transcending the distinction between first and second nature (Smith 2008:83). This move

quickly seems to lead Smith into muddling the crucial distinction between form and content-two internally related terms of a contradiction underpinning the dialectical movement at the core of Marx's theory of value (see Burkett 2014, Saito 2017). What Marx's value theory allows us to do, I wish to argue, is to conceptualize the irreducibility that defines any realist conception of nature as an internal determination of the contradictory historical socio-ecological development of the valueform. And, in particular, the fraught convergence, in the co-production of nature, of the production of value with the production of meaning; an issue to which I will return further below.

\section{Non-identity and socio-ecological contradictions}

In this sense, much of the critiques around Smith's thesis can be traced back to importance of the ways in which nature, both human and extra-human, stand in non-identical (yet not external) relation to its capitalist social forms. The importance of this relation cannot be overstated. As Malm 
(2018b) suggests, part of the enduring aesthetic allure of our inherited conceptions of 'nature' is that they still hold the capacity to evoke this constitutive irreducibility of life to the juggernaut of capitalist accumulation-in the words of Adorno, quoted in Malm, "natural beauty remains the allegory of this beyond" (2018b:28). Indeed, this relation of non-identity between form and content can be understood as the fundamental point of departure for critical thought, or more precisely, thought that is concerned with crisis. John Holloway formulates this as thinking "the world from our misfitting" (Holloway, 2010:9), from the ways in which our social life-process is not only constituted through the reified forms of capital, but against and beyond them: a ubiquitous misfitting that gives capitalist society (and ecologies) its immanent self-antagonistic and crisis-prone movement. In this sense, departing from the non-identity of form and content implies understanding capitalism not from domination, but "from the perspective of its crisis, its contradictions, its weaknesses..." (Holloway, 2010:9). From this starting point, "the only way in which we can understand the capitalist forms of social relations (and, at their centre, abstract labour) is as forms swollen with their own negation, forms that do not contain their content, but from which their content constantly overflows" (Holloway, 2010:188).

One should, however, be careful not to reintroduce here the division between nature and society rightly criticised by Smith, as this distinction is not coterminous with that between social form and material-practical content. On the contrary: these dialectics of non-identity implicates nature in both its human and extra-human moments-whether it is, to borrow Malm's line, a parrot's "exuberant indifference to the value-form" (Malm 2018b:28), or a worker's antipathy towards its compulsions. The ways in which human and non-human natures articulate and feed back into each other in the reproduction of these dialectics of non-identity remains in this sense a fundamental field of militant inquiry.

Perhaps this important point can be illustrated by turning to some long-standing questions related to value theory in agrarian studies. As mentioned earlier, this dialectic between the material life-process and its economic form-determinations underpins Marx's theory of value, and it can be seen to resurface strongly in his theory of differential rent (Marx, 1991). Ecological variability-e.g. different qualities of the soil, climate, etc.-runs necessarily counter to the homogenizing tendencies of the law of value-e.g. the equalisation of profit rates-as goods rendered equivalent in the market incorporate differential costs rooted in the inherently diverse ecological conditions in which agricultural production is embedded. When demand is such that harvests produced under less productive lands need be incorporated, these 'distort' the regulating market price, which then 
generates permanent 'surplus profits' or a differential rent for those producing on the best lands. Needless to say, this immanent resistance of nature to the homogenizing compulsion of capitalist markets has had a determinant importance for the historical development of agrarian social formations under capitalism. For instance, Mexican agrarian scholar Armando Bartra (2006) argued that for a long time differential rent constituted the structural basis for the persistence of the peasantry in peripheral capitalist countries (Latin America in particular) as states attempted to muffle this rent through the reliance for cheap food on a class of producers whose ties to the landassociated both to cultural and subsistence conditions-made them able to sustain production below the average rate of profit, often at the point of simple reproduction. In other words, for Bartra, the resistance that ecological variability necessarily poses to the operation of the law of value was one of the main conditions for the reproduction of socio-economically, culturally, and agroecologically intricate relations to the land in the Latin American countryside during the better part of the twentieth century.

To be sure, this strategy for securing cheap food (and lowering wages) at a national level went largely out the window in the neoliberal period, as production for national consumption was replaced by cheap food imports, and the lion's share of state subsidies went towards exportoriented capital-intensive production (Rubio, 2001). Nonetheless, the underlying contradictions have appeared in even more explosive forms as millions of people moved from being part of a structurally exploited class of agricultural producers to becoming a marginalized rural populationlarge segments of which have endured a generation-long simple reproduction 'squeeze' (Bernstein, 2001) - whose ways of life, and with it the historical and symbolic density of the land, often appear hopelessly anachronistic from the perspective of a globally rearticulated law of value (Rubio, 2001). These shifting tides in the international division of labour recasts a reconfigured, and particularly brutal, geography of rent in the form of, inter alia, intensified and expanded circuits of extraction (Arboleda, 2019), which have become a characteristic feature of Latin American rural landscapes and its political struggles, in neoliberal and 'postneoliberal' countries alike (Svampa, 2013; Gudynas, 2012; Webber, 2017). This renewed geography of rent, across its different periods, has provided the backdrop for the development of some of the most important popular movements in Latin America, such as the Zapatista Army of National Liberation (EZLN), or the Brazilian Landless Peasant Movement (MST), among many other indigenous movements, all of which have made worldhistorical ripples in the geographies of anticapitalist struggle (Rubio, 2001; Bernstein, 2001), and are inextricably linked to the material reproduction of a wealth of agro-biodiversity and traditional agro- 
ecosystems (Boege, 2008), the multiple values of which find little or no representation under the tempest unleashed by global market forces on agrarian social formations for over a generation.

And even in this context, capitalism's struggle with its natural foundations continues to impose in many places the reproduction of a relative exteriority within the agrarian landscapes of capitalism itself: that is, the reproduction, even if fragmented and pauperized, of diversity in both social and agroecological terms, in the shadows of the decrees of the world market. As Bartra (2006:25) notes, capitalist fantasies of a completely subsumed nature notwithstanding, the irreducible autonomy of the latter makes itself felt in the rhythms it imposes on agricultural production (cf. Mann and Dickinson, 1978), which seasonally concentrates the demand for labour on sowing and harvest periods. Seasonal labourers must however eat year-round, and thus peasant production and its associated moral economies continue to be reproduced as a constitutive feature of the landscape. To quote Bartra:

[I]n the end, what allows the specialized agribusiness entrepreneur to pay only for the workdays required is a diversification of crops that runs on the account of the employee and her family. This is illustrated by the capitalist plantations in the coastal valleys [in Mexico], which are only economically viable thanks to the peasant milpas ${ }^{4}$ in the mountains. This is to say, that, finally, productive diversification enters through the backdoor, associated in this case to the combination of two different immanent economic rationalities. (2006:25, my translation).

Returning to the idea of the production of nature and the way it understands value as a socioecological pivot, the preceding discussion suggests at least two points. On the one hand, Smith original critique of the nature/society binary risked losing sight of the dialectics of non-identity between internally related moments of social form and socio-metabolic content. On the other, this dialectic is fundamental to understand not only ecological contradictions, but also important aspects of social movements, and perhaps more crucially, the ways in which these two aspects relate internally to each other.

\section{The 'vernacular' and world-ecological totalization}

The above mentioned idea that capitalism, as a regime of value, and its particular accumulation strategies and shifting divisions of labour imply the reproduction of a relative exteriority-a field of non-commodified practices which although not directly constitutive of value, constitute 
nonetheless its conditions of possibility-has a long history within the Marxist tradition, stretching perhaps back to Rosa Luxemburg's ([1913], 2003) account of imperialism, through debates around the persistence of 'peasant' production within capitalism (Bernstein et al., 2018; Bartra, 2006; Ploeg, 2013; Bernstein, 2010), to the pathbreaking contemporary developments in the field of social reproduction theory (e.g. Arruzza, 2015; Bhattacharya, 2017). The theoretical and political force of this idea perhaps lies in the way it allows for an understanding of the internal and mutually constitutive nature of the relations between capitalism's impersonal mechanisms of domination and exploitation-i.e. class-divided social practice expressed in the compulsive dynamism of economic forms - with patriarchy, colonialism/racialisation, and ecological despoliation. One of the pioneering works in this sense was that of Maria Mies ([1986] 2014), who outlined the connections between the historical consolidation of the capitalist system, the emergence of a new relation to nature, the control over women's bodies through witch hunts, and colonial expansion and slavery. In her words, for the capitalist system to take root it was necessary for 'women, nature, and colonies' to be "externalized, declared to be outside civilized society, pushed down, and thus made invisible, as the under-water part of an iceberg is invisible, yet constitute the base of the whole" (Mies 2014:77). In this sense, the reproduction of capital's value regime can be seen to always entail the simultaneous reproduction of its ontological flip-side: a regime of non-value sustained through the reproduction of a complex web of forms of oppression.

More recently, this idea has been taken up and developed in a systematic fashion by Jason W. Moore (e.g. , 2015; 2017a), whose deeply original historical and theoretical work has had a very important impact in recent discussions within ecological Marxism, and ecological thought more generally. Developing a non-dualist world-systems perspective-i.e. 'world-ecological'-, the model proposed by Moore hinges on a dialectic of exploitation and appropriation inherent to capital's law of value. The establishment of socially necessary labour time as measure of value implies what Moore calls the historical production of an 'abstract social nature': the cultural and political mechanisms of legibility (Scott, 1998) and control that capitalist power imposes on the socioecological matrix through which capital accumulation takes place. For Moore, world-historical cycles of accumulation depend upon the production of an 'ecological surplus' through revolutions in the ability to appropriate unpaid human (e.g. unpaid domestic labour) and extra-human (e.g. soil, oldgrowth forests, etc.) work: the law of value is the law of 'Cheap Nature', i.e. the aggressive externalisation, devaluation, and appropriation of the 'web of life'. 
Moore's account of capital's world-ecological logic is undoubtedly generative and illuminating. Nevertheless, from the perspective I am developing here the model remains one-sided: the terms of its account of the concrete and contradictory movement of socio-ecologies remain those of capitalist domination-i.e. the law of 'cheap nature' as capital's form of world-ecological totalization. If, as I have argued, we consider socio-ecological reproduction and its capitalist formswhich, as Moore explains, encompass both an economic and a cultural moment; abstract labour and 'abstract social nature', respectively (Moore, 2017b) - to be characterised by a dialectical movement of non-identity, then the critical question would be that of how the negation-the law of value/cheap nature-is itself negated in the concrete life-process, in and against its alienated world-ecological totalization in capital. After all, from the point of view of those whose lives are 'cheapened' by capital, life is not actually cheap, but dear-and it is this fact that ultimately compels socio-ecological reproduction onwards. The dialectic described by Moore is that of the internal relations between capitalist forms of domination-sphere of capitalization and sphere of appropriation-but not that of the non-identity between both of these real abstractions and the concrete life-processes that are constituted through them. This is what I think has left Moore's model, despite his intentions, open to be read as a 'hyper-constructivist' position (e.g. Foster, 2016), in a manner similar to Smith's, as it confines its account of socioecological reproduction to the form it assumes from the standpoint of capital's world-ecological totalisation: the value-form and its cheap nature pedestal.

A seldom recognized distinction made by Ivan Illich might help to clarify this point. Illich (1980) distinguished between what he termed 'shadow work' - those unpaid forms of activity that only exist as the necessary complement of commodity production, and that are inextricable from it-and what he called 'the vernacular'. In its classical Latin usage, the word denoted "sustenance derived from reciprocity patterns embedded in every aspect of life, as distinguished from sustenance that comes from exchange or from vertical distribution" (Illich, 1980:85); a meaning that was later applied to language to signal the non-formal rootedness of the latter in the speaker's own relational grounds and everyday usage, as opposed to its formal abstraction and codification as part of the constitution of state power. For Illich, the word allows for greater precision and depth than that afforded by terms such as 'subsistence', which too often is taken as 'bare minimum material conditions for life' and reinforces economistic understandings of social practice. In contrast, the 'vernacular' encompasses a crucial dimension of human existence and practice-present in practices and forms of knowledge as diverse as music, childbirth, architecture, notions of 
reasonableness, preparation of food, the shaping of language and other forms of embodied competence, etc. - that is oriented to an embodied and contextually defined purpose, or telos. Illich was emphatic about the importance of the distinction that this word allowed within what is normally understood as 'social reproduction'. For Illich the fundamental opposition posed by modern society was not that between wage labour and its complementary 'shadow work', but between this binary - the dual form of capitalist domination-and the vernacular, everyday embodied relations of mutual constitution, which although fragmentary and arguably receding, constitute a "mode of being, doing, and making" irreducible to abstract formalization and quantification, one productive of its own immanent teloi.

Illich's notion of the vernacular nevertheless encounters its limits in the extent to which it posits this realm of human practice as 'external' to capitalist modernity and its historical development. Instead, here I want to push Illich's notion further: the 'vernacular' does not necessarily designate different kinds of practice-i.e. modes of being external to capitalist modernity-, but more fundamentally, different dimensions of practice within capitalist society. Operating within Marx's dialectic of the concrete and abstract dimensions of capitalist labour, the vernacular, embodied orientation towards a contextually defined telos should be seen as internal to every form of labour, even if it appears only in its negated form-inter alia, as class struggle (cf. Cleaver, 1992).

More specifically, and for example, under capitalist relations of production the labour process is a site where contradicting teloi co-exist: while from the standpoint of capital this process is ultimately faced from the abstract imperative of profitability, for its constitutive powers -i.e. workers - the same process is ultimately faced from the rather more grounded imperatives and values that arise from reproduction and enhancement of their life-worlds. In the constitutive metabolic moments of capital's valorisation, the material acts involved thus appear as sites of conflicting valuations-something well illustrated in Marx's detailed examination of the struggles around the definition of the working day (Marx, 1990). Regardless of the imposition of abstract determinations, or rather precisely because of them, at the level of concrete practice, the labour process is beset by innumerable acts that from the point of view of capital's valorisation constitute instances of 'indiscipline' or resistance which cannot be ignored when approaching the material constitution of the landscape, nor the particular forms taken by accumulation strategies, or the reified concepts of movement of capital itself (above all, profitability). This does not mean that these acts are necessarily consciously articulated as 'resistance', rather, they appear as such from the point 
of view of the accumulation process and its imperatives of abstraction, legibility, fetishization, and expansion.

As a thoroughly internal moment of capitalist society, the 'vernacular' should not be understood as an ahistorical category; on the contrary, it is an immanent critical one-a concept internal to capital as a totalising movement of abstraction-rooted in the contradiction between the socio-ecological reproduction and its social form; a contradiction that can be seen condensed in Marx's analysis of the structure of the commodity as fractured by its existence as value and usevalue. And as the basis for use-value, the concrete historical instantiations of the vernacular dimensions of life are inextricable from the historical development of the social form of capital: capitalism produces its own forms of vernacular practices, values, and consciousness. Moreover, although there are of course properties that are specific to human practice (which will concern the rest of this paper), at the most general level of abstraction 'the vernacular' can be seen to implicate the practically infinite layers of autopoietic activity that make up the biosphere, which cannot but persevere, at the most basic level, in their autonomy.

If, as Moore holds, following Federici, "it is precisely the symbolic erasure, the invisibilization, of care work that has been the necessary condition of capitalist development" (Moore, 2017c:330), the question becomes how do we think against this invisibilisation, how do we think from that which is being invisibilised? Think for example of a river: as abstract social nature it might appear as 'energy', as cartography, as quantifiable magnitudes of various kinds; as value it might appear in the form of the potential rents generated by the establishment of a hydropower project. But what is being negated in these specific forms? The river as a life-process, co-produced by the symbolic and historical density of its human relations, and the infinite complexity of the nonhuman layers of activity that make up its ecology. If the task of articulating a revolutionary politics for a different conception of the values mediating our mutual constitution is not to fall into idealist utopianism, we must attend to their immanent grounds in our actually existing life-process: in the ways in which socio-ecological reproduction is necessarily compelled onward, in spite of everything, through the relentless vernacular reproduction of meaning, purpose, and value(s). This is a process, to be sure, fragmented, incoherent, and contradictory. But at the same time it constitutes the only possible cultural-practical basis for the political composition of the necessary negation of the 'cheapening' of life that sustains the ongoing cataclysm of world-ecological totalization under capital's value regime. In rooting our politics and our critique in the relations that constitute the vernacular sites of non-identity, we might find the grounds for the oppositional reenchantement of 
nature that Neil Smith, writing over a decade after his original thesis, thought to be a still unfulfilled task for the left (Smith, 1998). And it is here where the recovery of the theoretical importance of the category of use-value-which Bolívar Echeverría considered to be the "implicit conception that sustains the entire edifice of the critique of political economy" (2014:24)-becomes clear.

\section{Production and the perspective of use-value: on Echeverría's critical theory and anthropological theories of value}

In these final sections I want to turn to a combined reading of the work of Echeverría, and anthropological theories of value-in particular as developed in the work of Terence Turner and subsequently by David Graeber-, in order to move beyond a flat physicalist and/or utilitarian conception of use-value, and towards a better account of the concrete actualization of capitalism as a contradictory articulation of abstraction and meaning.

Echeverría's Marxism treaded paths notably divergent from the mainstream of Latin American Marxism of his day (1980s and 90s); which, often pray to the combined pressures of ossified dogmatisms and rising postmodern intellectual hegemony, was at the time characterised by its receding influence and marked by political defeat. Echeverría, in part motivated by what he perceived as the failings of the orthodox Marxist tradition, developed a non-economistic understanding of the value-theoretical aspects of Marxian critique to make sense of the specificities of capitalist modernity in the history of Latin America; an endeavour through which he developed a distinctly non-Eurocentric reading of Marx, and of modernity itself. On the basis of a critical reconstruction of the category of use-value-the subsumption of which he considered to be the foundational contradiction of capitalist modernity, and the core of Marx's critique (see Echeverría, 2014)-, Echeverría gave deeply original accounts of issues like cultural form, peripheral modernity, and mestizaje, among many others (see Barreda, 2011; Sáenz De Sicilia and Brito Rojas, 2014).

It is important to distinguish here the sort of materialism that underpins Echeverría's - and to a great extent, as I will explain below, Turner's-reading of Marx, and his reconstruction of the category of use-value. This is a materialism which has little to do with 'matter' itself (Toscano, 2014). Rather, it is one that departs from Marx's reflexions in his Theses on Feuerbach (Marx, 2002; see Echeverría, 2011: 437-469), of how the 'contemplative'/externalised representation of a material word stripped from an active subject of traditional materialism is but the inverted expression of the idealist conception of active subjectivity in abstraction from the practical world. This was an impasse 
that Marx sought to escape through grounding his materialism on "revolutionary, practical-critical activity" - the subjective, transformative practical engagement with the world. For Marx, however, the differentia specifica of human practical activity is precisely the fact that its concrete forms are not given by an ahistorical nature (Marx, 2005), thus positing, for a critical materialism, the problem of "the history of the forms or socio-political modes within which the human life-process takes place; it must be configured as historical materialism" (Echeverría 2011:442, my translation; c.f. Murray, 2016).

This conception of materialism is what underpins Echeverría rejection of the common reductive reading of use-value as the mere physical content of the social form of value. What makes the 'needs' satisfied by use-value specifically human is that they are irreducible to some unmediated instance of 'natural' requirements, but only exist through a movement of transnaturalisation (Echeverría, 2014) into specific cultural forms. The notion of 'use', in short, is necessarily defined in relation to a particular telos; it is implicated in social and moral universes in relation to which both subjective activity and practical objects acquire meaning (ibid.; cf. Sahlins, 2013). For Marx's purposes of building a critique of political economy, the point of the concept of use-value is the identification of a dialectical tension within structure of the commodity form: it distinguishes between the needs defined by the expansive accumulation process and the needs of concrete human subjects, aspects which under capitalist social relations develop as contradiction. Use-value thus fundamentally functions as a category of contrast, one whose dialectical relation to value as a measure of socially necessary labour time makes way for Marx's critique of political economy. However, as Echeverría pointed out (2014), although crucial, use-value is a category left comparatively undeveloped within Marx's work.

To move in this direction, I think it is necessary to interrogate the notion of 'production' from the point of view of use-value. Here, as I will explain below, the concerns of Echeverría and those of Turner and Graeber overlap in significant ways. Echeverría reminds us that to "produce is to objectify, to inscribe in the form of the product a transformative intention addressed to the subject itself" (2014:29). In this sense, from the point of view of use-value, the social production of objectivity is a subordinate aspect within a process ultimately oriented towards the production of a particular form of (social) subject (cf. Graeber, 2007: 95). And for Echeverría, it is the capacity of the social subject to give form to its constitutive relations of interdependence that defines its subjecthood [sujetidad], a movement through which "its identity and the differential identity of its members" is constituted (Echeverría, 2014:27), and through which a structural social telos is 
founded. Production, from the point of view of use-value, can only ultimately be the symbolicmaterial production of particular kinds of persons, and, more precisely, the horizons of meaning in which the values that orient their life-activity are reproduced, or contested (c.f. Graeber 2001, 2007).

Arguing in a similar direction, anthropologist David Graeber (2007:94) calls attention to Marx's comments in his ethnographic notebooks, where he points out that

Among the ancients, we discover no single enquiry as to which form of landed property ... creates maximum wealth. Wealth does not appear as the aim of production ... The enquiry is always about what kind of property creates the best citizens. ...

Thus the ancient conception, in which man always appears (in however narrowly national, religious, or political a definition) as the aim of production, seems very much more exalted than the modern world, in which production is the aim of man and wealth the aim of production. (Marx, 1965:84)

Marx here notes the particularity of capitalist modernity, the barbaric inversion inflicted by capitalistically constituted production onto the social life-process: that "in which production is the aim of man [sic] and wealth the aim of production". The objective dimension of the social lifeprocess - which consolidates as the discrete sphere we know today, i.e. the economy, with the generalization of the commodity-form as social nexus, and its autonomisation as capitalconstitutes itself as an 'automatic subject', in relation to which the social life-process becomes structurally devalued as a mere means, caught in the unending treadmill of valorisation (Postone, 1993). In this context, from the perspective of Echeverría use-value appears as an immanent critical concept, one which "shatters" this horizon of modern thought (Echeverría, 2014:24), and allows for the articulation of a critical discourse. This critique sheds light on the way the concrete organization of social reproduction under capitalist modernity is torn by the perennial struggle of the 'spectral' inversion of the value-form to subsume the 'socio-natural form' ${ }^{5}$ of social reproduction signalled by the concept of use-value (Echeverría, 2011:283). The central political struggle posited by capitalist modernity is, for Echeverría, one over the form-determination of social reproduction (Sáenz De Sicilia \& Brito Rojas, 2014).

As mentioned earlier, the problematisation of 'production' entailed in Echeverría's analysis of use-value resonates in interesting and in my view quite productive ways with a different stream of scholarship within anthropology which has developed a Marxian approach to the question of value (see Graeber, 2001). The ethnographic focus of this latter body of work develops a very similar 
conception of social form and production at more concrete levels. The pioneering author here is the late Terence Turner, who in his work with the Kayapo in central Brazil took the comparative analysis of production in a quite different direction from that developed by other streams of Marxian anthropology (e.g. Godelier, 1977). These, despite their often sophisticated development of the base/superstructure metaphor and 'the economic' as determinant instance, generally tended to assume the universal validity of the latter category, which remained central to the definition of what 'production' is about (Kahn and Llobera, 1980). Turner, instead, departed from the kind of materialism implied in Marx's form analysis, as explained above. For him, Marx's value theory provided an immensely powerful form of materialist symbolic analysis. Turner argued that "the definition of what counts as 'production' in any society is ethnographically inseparable from how it defines the need (or needs) that serve as the focus (or foci) of its productive activities" (Turner, 2008: 45). In capitalism, the alienated productive actions of social subjects are systematically pinned against each other in the form of market competition of individual capitals, which in turn produces the systemic compulsion for the ever-expanding valorisation. This ultimate systemic need

... is on a different level from the more mundane needs for material subsistence and services satisfied by the commodities produced by capitalist firms. Rather, it is the structural necessity whose satisfaction constitutes the aim of all the productive activities comprising the capitalist system as a whole. It thus (an important point here for anthropological purposes) reflexively becomes the criterion for defining which activities count as 'productive' and therefore as creating value in a capitalist economy. (Turner, 2008:45, my emphasis.)

Turner here is historicizing what is deemed to be the object of production in relation to which what is considered to be productive activity is defined in any given system of social action ${ }^{6}$. In the case of the Kayapo, Turner argues,

... social production, in the absence of markets and production of commodities for exchange (ie, of 'economies'), is concerned above all with the production of social persons and relations, and the social values attaching to them. The production of subsistence goods and services, while important, appears as an ancillary aspect of the process of (re-)producing social persons and the families and extended family relations that serve as the organizing framework of this process, rather than a distinct, separately institutionalized domain of production and exchange: that is, not as an 'economy'. (Turner, 2003:11)

Following Marx's insights, for Turner the 'values' that reflexively define what sorts of activities are considered to be 'productive' in any given society constitute the symbolic mediations through which 
individual actions are oriented, and meaningfully integrated into an interdependent totality of practices. Value is the way in which individual actions acquire social meaning (Graeber, 2001). Turner shows the main categories of social value among the Kayapo to be "beauty" and "power"; aspects of the identity of persons that are produced by the Kayapo system of social production, realised by particular persons in particular ritual settings, and to which its own mechanisms of exploitation are articulated (Turner, 1984; 2003; 2004). Value(s) in this sense delineate and structure social worlds which are understood "not just as a collection of persons and things but rather as a project of mutual creation, as something collectively made and remade" (Graeber, 2013:222). Turner's conception of value (linked to his anti-economistic materialist conception of production) in this sense functions in a manner analogous to that which Echeverría called 'social telos': it gives a definite form to society's relations of interdependence, and in turn constitutes the symbolic mediations through which individual actions acquire their social meaning and orientation. From this point of view, as David Graeber-a former student of Turner who took up the latter's largely unpublished project-points out, 'cultures' and 'societies' appear as projects for the pursuit of a particular form of value (or, more commonly, a constellation of these); projects that by definition imply collective conceptions of both the meaning of human existence, and the nature of the world; i.e. cosmologies (Graeber, 2013).

These ideas open up new dimensions to Smith's thesis on the 'production of nature', and in my view lay the basis for a common materialist understanding of cultural and economic registers of the concept of 'value'. In the words of Echeverría (2014:27): "the confrontation of the subject with nature... [is] an indirect confrontation, mediated by the confrontation of the subject with its own sociability." Value is, in the sense developed by Turner, not only generative of cosmologies and conceptions of the world, but constituted by and generative of particular forms of social praxis, structuring the way metabolic relations are socio-symbolically mediated, and therefore, following Smith's argument, a pivotal moment in both the material and symbolic constitution of particular historical ecologies.

\section{Value, struggle and the production of nature.}

One of the relevant implications of Turner's approach is that value as an economic form, and 'values' as moral-cultural "conceptions of the desirable" are to be understood as different refractions of a common process through which human practical action is confronted with and 
integrated into its own social universe of meaning (Graeber, 2001:78). It is worth unpacking this relation a bit further. What I think Turner's approach casts into relief are some of the key implications of Marx's account of social form, and what one could call the basic elements of his semiotic-materialist approach (cf. Saenz De Sicilia and Rojas, 2018). In Marx's value theory, the capitalist form-determination of social reproduction can be described in the following terms: as primitive accumulation fragments socio-ecological relations and establishes the private and alienated character of capitalist labour, the irreducibly social character of human practice comes to exist in the form of 'abstract labour'/value, and is expressed through a symbolic attribute of the commodity-its exchange-value. This attribute can in turn only be realised and defined in relation to a social totality, ultimately constituted by the world market. In Marx's account of value one can discern three internally related aspects of social reproduction that are organised in the historical form of 'value': meaning (as value), practice (as labour), and sociality (as market). In other words, Marx's theory of value as a broader theory of social form implies positing 1 . the social and symbolic nature of human practice, 2 . the practical and social nature of symbolic meaning, and 3 . the symbolic and practical nature of social relations. The conception of social reproduction entailed by Marx's materialist analysis is therefore one in which human subjective practice is inextricably linked to a socially defined telos/purpose/meaning/value, which is in turn reproduced through the integration of subjective practice into a particular social/relational field, which is consequently constituted and defined by a set of meaningfully concatenated practices.

The realm of use-value, in this sense, can be seen as the variegated vernacular substratum of practice, sociality and meaning in which socio-ecological reproduction-including that which is capitalistically organised-must always be rooted: value, as pure abstraction, can only find its ultimate social validation in so far as it can anchor itself in the field of use-value. All economies must ultimately be in some sense 'moral economies'. In this sense, what Turner's and Graeber's work suggests is that Marx's value theory might provide the elements for a more general symbolicmaterialist theory of social form and of production, one that might recover the largely neglected field of use-value from the flat utilitarianism it has been often confined to, and towards an understanding of it as field of social relations and practices in which the meanings, purposes and identities driving socio-ecological reproduction are reproduced and contested.

As Graeber highlights, from Turner's project there emerges a conception of politics in which "[t]he ultimate stakes ... is not the struggle to appropriate value; it is the struggle to establish what value is" (Graeber, 2001:88); i.e. the determination of the meaning(s) of our lives, as active, practical 
processes. For Graeber, values necessarily delineate and instantiate the imaginary totalities in which they are realised, albeit to a necessarily partial and fragmentary extent. These are social fields that constantly overlap: "[i]n any real social situation, there are likely to be any number of such imaginary totalities at play, organized around different conceptions of value" (Graeber, 2001:88), conceptions from which particular worldviews emerge and claims about reality are made. Much of daily life, from this point of view, consists in the struggle, articulation, or otherwise knitting together of these different fields (cf. De Angelis, 2007). In the face of this view of society as a "thousand totalities", as Graeber puts it, it is however necessary to remain aware of the importance of the dialectics signalled by the antagonism of value and use-value central to Marx's critique of capitalist society. For Graeber, contra conceptions of our age as one characterised by the contingency, multiplicity, and proliferation of values, our current situation should be understood as above all "one in which the most gigantic, totalizing, and all-encompassingly universal system of evaluation known to human history came to be imposed on almost everything" (Graeber, 2001:89). In this sense, the expansive movement of subsumption that characterises capitalism imposes upon multiplicity the dialectics of antagonism and non-identity signalled by Marx's categories of value and use-value. Dialectics, rather than effacing multiplicity, is the awareness of the antagonism created by a totalising value system, and thus the negative character through which this multiplicity exists as a consequence of its subsumption (Holloway et al., 2009). The assertion of difference and multiplicity is not something that can be done theoretically - perhaps one of the characteristic ideological moves of liberalism, it must be resolved in (anticapitalist) practice.

Here is where it is necessary to return to Echeverría. In his reading, from the point of view of Marx's critique, capitalist modernity is

ruled simultaneously by two structuring principles which are inherent to it; two coherences or rationalities in contradiction to each other: that of the mode or the 'natural form' of life and its world and that of the mode or the 'value form' ... of the same. They are, in addition, two 'logics' in which the second, that of 'value', is permanently in process of dominating over the first, the 'natural', of 'subsuming' it. (Echeverría, 2011:281, my translation)

For Echeverría, although permanently asserting its dominance, the process of abstract valorisation remains necessarily parasitic: as a purely abstract, 'spectral' inversion it cannot posit its own qualitative content, it is dependent for its anchors of meaning on the use-value dimension of the social reproduction-what from Graeber's point of view is the field of 'values'. The concrete actualization of the capitalist organisation of socio-ecological reproduction thus remains torn 
between these two dimensions: an intricate and fraught articulation of abstraction and meaning, of value and use-value, in which capitalist cultural forms-its specific iterations of domination, resistance, and adaptation-emerge. The crucial task facing an inquiry into the political ecology of capitalist development is to understand this conflictual articulation, the torn existence of capitalism as a world-ecological project.

\section{Conclusion}

My intention in this paper was to contribute to current discussions on value theory and nature within geography by bringing together previously disconnected strands of literature, and developing what I think are the underexplored, but in my view very significant, openings that this combined reading offers.

In the first place, Marx's value theory-being a theory about the social form of our practical engagement with extra-human world and each other-allows us to understand value as a material force actively shaping socio-ecological relations on this planet. Foregrounding this was the early, and crucial, contribution of the production of nature thesis to this question. Nevertheless, the contradictions that characterise the concretion of the abstract logic of valorisation have been insufficiently understood, often generating the apparent hiatus between our understanding of the abstract and concrete dimensions of capitalist socio-ecologies (Ekers and Loftus 2013), sometimes reducing one to the other, and/or running the risk of blunting the edge of value theory for an historically and geographically grounded analysis.

Following Echeverría, I have argued that the category of use-value is the point of departure of Marx's value theory as critique. Often interpreted in flat utilitarian or physicalist terms, the category should instead be understood as signalling the necessary horizons of meaning in which human practical actions and relations, as well as practical objects, are embedded, a domain valorisation-as process of abstraction-must always ultimately refer back to. In this sense, the socio-ecological concretion of the law of value is always characterised by a dialectal relation of nonidentity between internally related moments of abstraction, meaning, and life-making, all of them simultaneously rooted in everyday practical activity. Through this process, the intricate-often baroque (Echeverría 2011)-cultural, political, and ecological forms of contemporary capitalist landscapes develop. And it is here where both political openings and dangers must be sought. 
For this reason, attention to what, drawing from Ivan Illich, I have called 'the vernacular' is of critical importance: it constitutes the basic cultural-material grounds for the composition of historically and geographically situated anti-capitalist politics. As mentioned above, we need to approach our situation from that which is negated by the mechanisms of capitalist value and power-abstract labour and abstract social nature (Moore, 2015) - , a dimension that nevertheless must continue to exist as the locus of the meaning-making processes that ultimately drive social reproduction at its base. Drawing on anthropological theories of value, I have suggested that Marx's theory of value might offer some core elements for a symbolic-materialist approach to this field; by rooting cultural values in material practices, and delineating the relational fields in which these practices acquire and realise their cultural meanings and orientations. This approach might allow us to connect more clearly cultural values to the specific ecologies and geographies through which they are reproduced.

These openings offered by value theory might help us sketch the myriad social-relational fields in which socio-ecological reproduction is embedded, and grasp the practical-material and relational conditions for the moral and cultural values that permeate our social metabolism at every point. However, it is important to understand that these values and their attendant ecologies and geographies emerge within, and develop through-sometimes beyond-the geographies and ecologies of capital (and vice versa). In other words, what we are everywhere confronted with are not discreet 'regimes of value', but an overlapping multiplicity that under the hegemony of the capitalist value regime can only exist through the dialectic between value and use-value. Marx's critique still offers us a unique avenue to understand this - and act upon it.

\section{Acknowledgements}

The ideas presented here have greatly benefited, at different points of their development, from the comments of Alex Loftus, Nicholas De Genova, Andrés Sáenz de Sicilia, Martín Arboleda, Hannah Schling, Archie Davies, Scott Prudham, and David Graeber, who provided Turner's unpublished material. I am also grateful for the helpful comments of two anonymous reviewers.

\section{Declaration of conflicting interests}

The author(s) declared no potential conflicts of interest with respect to the research, authorship, and/or publication of this article 


\section{Funding}

This research was funded by the National Commission for Scientific and Technological Research of Chile (CONICYT).

\section{Notes}

${ }^{1}$ The arguments in this paper draw from the ongoing discussions within the rich field of critical readings of Marxian value theory-a stream of debates arguably stretching from Isaak Rubin's Essays on Marx's Theory of Value (1973 [1928]), but running through the discussions associated to the German Neue Marx-Lektüre (see Heinrich, 2007; Bellofiore and Redolfi Riva, 2015), and, in the anglophone world, those associated with the Open Marxist school (e.g. Bonefeld, 2014; Holloway, 2010), the Conference of Socialist Economists (e.g. Clarke, 1991; Elson, 2016), among many others (Postone, 1993; Murray, 2016). Although itself immensely variegated, this field of discussions is characterised by the centring and development of Marx's understanding of value as an historically specific form of the social character of labour (or, in other words, of society's metabolic relation to nature).

${ }^{2}$ In Marx's theory there is a distinction between value-a relational property emergent from private (not directly social) character of capitalist labour-and exchange-value, as the expression of this relation in exchange.

${ }^{3}$ Among the exceptions, if somewhat different in orientations, is the work of Burkett (2014, ch 7), and more recently, of Jason W. Moore (e.g. 2015) and Kohei Saito (2017).

${ }^{4}$ Milpa is the main traditional agroecosystem in Mesoamerica, based on the association of maize, beans, and squash.

${ }^{5}$ For Echeverría the term 'natural form' "does not make reference to a 'substance' or 'human nature' of metaphysical validity, against which the 'value form' would be 'in sin'; nor to the rootedness of the human in Nature's normativity, in relation to which the 'value form' would be a mere artifice lacking any basis. It refers exclusively to the fact that that which is human, being in essence 'artificial', non-natural, that is, contingent, self-founded, must always constitute its forms in an act ... of 'trans-naturalisation', act that makes them forms constituted on the basis of proto-forms located in nature, the same which, 'determinately negated', remain as its substance." (Echeverría, 2011:281, my translation).

${ }^{6}$ I make the last revisions to this manuscript amid a global pandemic that, among other things, has forced valorisation to take, for the time being, a backseat to the preservation of life. One of the notable consequences of this temporary unsettling in our hierarchies of value has been the sudden inversion of hegemonic notions of which work is valuable/essential, and which expendable. This speak directly to Turner's point here.

\section{References}

Andreucci D, García-Lamarca M, Wedekind J, et al. (2017) "Value Grabbing": A Political Ecology of Rent. Capitalism Nature Socialism 28(3): 28-47.

Arboleda M (2019) From Spaces to Circuits of Extraction: Value in Process and the Mine/City Nexus. Capitalism Nature Socialism. DOI: 10.1080/10455752.2019.1656758. 1-20.

Arruzza C (2015) Functionalist, Determinist, Reductionist: Social Reproduction Feminism and its Critics. Science \& Society 80(1): 9-30.

Bakker K and Bridge G (2006) Material worlds? Resource geographies and the 'matter of nature'. Progress in Human Geography 30(1): 5-27. 
Barreda A (2011) En torno a las raíces del pensamiento crítico de Bolivar Echeverría Bolívar Echeverría: Crítica de la modernidad capitalista. La Paz: Vicepresidencia del Estado Plurinacional de Bolivia.

Bartra A (2006) El capital en su laberinto: de la renta de la tierra a la renta de la vida. México: UACM.

Bellofiore R and Redolfi Riva T (2015) The Neue Marx-Lektüre: Putting the critique of political economy back into the critique of society. Radical Philosophy.(189): 24-36.

Bernstein H (2001) 'The peasantry'in global capitalism: who, where and why? Socialist Register $37(37)$.

Bernstein H (2010) Class Dynamics of Agrarian Change. Halifax and Winnipeg: Fernwood Publishing.

Bernstein H, Friedmann H, van der Ploeg JD, et al. (2018) Forum: Fifty years of debate on peasantries, 1966-2016. The Journal of Peasant Studies 45(4): 689-714.

Bhattacharya T (2017) Social Reproduction Theory: Remapping Class, Recentering Oppression. London: Pluto Press.

Bigger P and Robertson M (2017) Value is Simple. Valuation is Complex. Capitalism Nature Socialism 28(1): 68-77.

Boege E (2008) El patrimonio biocultural de los pueblos indígenas de México. Hacia la conservación in situ de la biodiversidad y agrobiodiversidad en los territorios indígenas. INAH, México 33.

Bonefeld W (2014) Critical Theory and the Critique of Political Economy: On Subversion and Negative Reason. London and New York: Bloomsbury.

Bonefeld W (2018) Wealth and Suffering: On Capital, Chapter I. Dialogue and Universalism 28(3): 123-140.

Bonefeld W, Gunn R and Psychopedis K (1995) Open Marxism: Emancipating Marx. Pluto Press. Braun B (2008) Environmental issues: inventive life. Progress in Human Geography 32(5): 667-679. Burkett $\mathrm{P}$ (2014) Marx and nature: $A$ red and green perspective. Palgrave Macmillan US.

Castree N (1995) The nature of produced nature: materiality and knowledge construction in Marxism. Antipode 27(1): 12-48.

Christophers B (2016) Risking value theory in the political economy of finance and nature. Progress in Human Geography 42(3): 330-349.

Clarke S (1991) Marx, Marginalism and Modern Sociology London: Palgrave Macmillan.

Cleaver H (1992) The inversion of class perspective in Marxian theory: From valorisation to selfvalorisation. In: Bonefeld W, Gunn R and Psychopedis K (eds) Open Marxism Vol 2. London: Pluto Press, pp.1992-1106.

De Angelis M (2007) The beginning of history: Value struggles and global capital. London: Pluto Press.

Eaton E (2011) On the Farm and in the Field: The Production of Nature Meets the Agrarian Question. New Political Economy 16(2): 247-251.

Echeverría B (2011) Bolívar Echeverría: Crítica de la modernidad capitalista. La Paz: Vicepresidencia del Estado Plurinacional de Bolivia.

Echeverría B (2014) 'Use-value': ontology and semiotics. Radical Philosophy.(188): 24-38.

Ekers $M$ and Loftus A (2013) Revitalizing the production of nature thesis: A Gramscian turn? Progress in Human Geography 37(2): 234-252.

Ekers M and Prudham S (2017) The Metabolism of Socioecological Fixes: Capital Switching, Spatial Fixes, and the Production of Nature. Annals of the American Association of Geographers 107(6): 1370-1388. 
Ekers M and Prudham S (2018) The Socioecological Fix: Fixed Capital, Metabolism, and Hegemony. Annals of the American Association of Geographers 108(1): 17-34.

Elbe I (2013) Between Marx, Marxism, and Marxisms--Ways of Reading Marx's Theory. Viewpoint Magazine 21.

Elson D (2016) Value: The representation of labour in capitalism. Verso Books.

Foster JB (2016) Marxism in the Anthropocene: Dialectical Rifts on the Left. International Critical Thought 6(3): 393-421.

Godelier M (1977) Perspectives in Marxist anthropology. Cambridge University Press.

Graeber D (2001) Toward An Anthropological Theory of Value: The False Coin of Our Own Dreams. New York: Palgrave.

Graeber D (2007) Turning modes of production inside out or, Why capitalism is a transformation of slavery. In: Graeber D (ed) Possibilities: Essays on hierarchy, rebellion and desire. Oakland: AK Press, pp.85-112.

Graeber D (2013) It is value that brings universes into being. HAU: Journal of Ethnographic Theory 3(2): 219-243.

Greco E and Apostolopoulou E (2019) Value, rent, and nature: The centrality of class. Dialogues in Human Geography. DOI: 10.1177/2043820619876386. 2043820619876386.

Gudynas E (2012) Estado compensador y nuevos extractivismos. Las ambivalencias del progresismo sudamericano. Nueva sociedad.(237): 128-146.

Gudynas E (2019) Value, Growth, Development: South American Lessons for a New Ecopolitics. Capitalism Nature Socialism 30(2): 234-243.

Heinrich M (2012) An introduction to the three volumes of Karl Marx's Capital. New York: Monthly Review.

Holloway J (2010) Crack capitalism. London and New York: Pluto Press.

Holloway J, Matamoros F and Tischler S (2009) Negativity and Revolution: Adorno and political activism. In: Holloway J, Matamoros F and Tischler S (eds) Negativity and Revolution: Adorno and Political Activism. London: Pluto Press, pp.3-11.

Huber M (2016) Resource geographies I: Valuing nature (or not). Progress in Human Geography 42(1): 148-159.

Illich I (1980) Vernacular Values. Philosophica 26(2): 47-102.

Kahn JS and Llobera JR (1980) French Marxist anthropology: Twenty years after. The Journal of Peasant Studies 8(1): 81-100.

Kallis G and Swyngedouw E (2018) Do Bees Produce Value? A Conversation Between an Ecological Economist and a Marxist Geographer. Capitalism Nature Socialism 29(3): 36-50.

Kay K and Kenney-Lazar M (2017) Value in capitalist natures: An emerging framework. Dialogues in Human Geography 7(3): 295-309.

Kenney-Lazar M and Kay K (2017) Value in Capitalist Natures. Capitalism Nature Socialism 28(1): 33-38.

Loftus A (2017) Political ecology I: Where is political ecology? Progress in Human Geography. DOI: 10.1177/0309132517734338. 0309132517734338.

Luxemburg R (2003) The accumulation of capital. Routledge.

Malm A (2016) Fossil Capital. The Rise of Steam Power and the Roots of Global Warming. London and New York: Verso Books.

Malm A (2018a) The Progress of This Storm: Nature and Society in a Warming World. London: Verso.

Malm A (2018b) In wildness is the liberation of the world: On maroon ecology and partisan nature. Historical Materialism, 26(3), 3-37. 
Mann SA and Dickinson JM (1978) Obstacles to the development of a capitalist agriculture. The Journal of Peasant Studies 5(4): 466-481.

Marx K (1965) Pre-Capitalist Economic Formations. New York: International Publishers.

Marx K (1990) Capital: A Critique of Political Economy, Volume I. London: Penguin.

Marx K (1991) Capital: A Critique of Political Economy, Volume 3. London: Penguin.

Marx K (2002) Theses on Feuerbach.

Marx K (2005) Grundrisse: Foundations of the critique of political economy. Penguin UK.

Mies M (2014) Patriarchy and accumulation on a world scale: Women in the international division of labour. London: Zed Books.

Moore JW (2015) Capitalism in the Web of Life: Ecology and the Accumulation of Capital. London and New York: Verso.

Moore JW (2017a) The Capitalocene Part II: accumulation by appropriation and the centrality of unpaid work/energy. Journal of Peasant Studies 45(2): 237-279.

Moore JW (2017b) Value in the web of life, or, Why world history matters to geography. Dialogues in Human Geography 7(3): 326-330.

Murray P (2016) The Mismeasure of Wealth: Essays on Marx and Social Form. BRILL.

Ploeg JDvd (2013) Peasants and the art of farming : A Chayanovian manifesto. Winnipeg: Fernwood.

Postone M (1993) Time, Labor, and Social Domination: A Reinterpretation of Marx's Critical Theory. New York: Cambridge University Press.

Purcell TF, Loftus A and March H (2019) Value-rent-finance. Progress in Human Geography. DOI: 10.1177/0309132519838064. 0309132519838064.

Robertson ¥ MM and Wainwright JD (2013) The Value of Nature to the State. Annals of the Association of American Geographers 103(4): 890-905.

Rubio B (2001) Explotados y Excluidos. Los campesinos latinoamericanos en la fase agroexportadora neoliberal. México: Plaza y Valdés-Universidad Autónoma de Chapingo.

Sáenz De Sicilia A and Brito Rojas S (2014) Introduction to Bolívar Echeverría. Radical Philosophy.(188): 20-23.

Saenz De Sicilia A and Rojas SB (2018) Production=signification: towards a semiotic materialism. Language Sciences 70: 131-142.

Sahlins M (2013) On the culture of material value and the cosmography of riches. HAU: Journal of Ethnographic Theory 3(2): 161-195.

Saito K (2017) Karl Marx's Ecosocialism: Capital, Nature, and the Unfinished Critique of Political Economy. New York: Monthly Review Press.

Schmidt A (2014) The Concept of Nature in Marx. London and New York: Verso.

Scott JC (1998) Seeing Like a State: How Certain Schemes to Improve the Human Condition Have Failed. New Haven: Yale University Press.

Smith N (1998) Nature at the millenium: production and reenchantment. In: Braun B and Castree N (eds) Remaking Reality: Nature at the Millenium. London: Routledge, pp.269-282.

Smith N (2007) Nature as Accumulation Strategy. Socialist Register 43(43).

Smith N (2008) Uneven Development: Nature, Capital, and the Production of Space. Athens and London: University of Georgia Press.

Sullivan S (2017) The disvalues of alienated capitalist natures. Dialogues in Human Geography 7(3): 310-313.

Svampa MN (2013) Consenso de los commodities y lenguajes de valoración en América Latina. Svampa, Maristella Noemi; Consenso de los commodities y lenguajes de valoración en América Latina; Fundación Friedrich Ebert; Nueva Sociedad 244: 4. 
Toscano A (2014) Materialism without matter: abstraction, absence and social form. Textual Practice 28(7): 1221-1240.

Turner T (1984) Production, Value and Exploitation in Marx and in Non-Capitalist Systems of Social Production. Unpublished essay

Turner T (2003) The beautiful and the common: inequalities of value and revolving hierarchy among the Kayapó. Tipití: Journal of the Society for the Anthropology of Lowland South America 1(1): 11-26.

Turner T (2004) The Transformation of Marx's Concept of Commodity Value to the Value of Social Products in Non-Commodity Producing Societies. In: Marxian Horizons: Critical Social Theory for the 21st Century. Ithaca, NY.

Turner T (2008) Marxian value theory: An anthropological perspective. Anthropological Theory 8(1): 43-56.

Wainwright J and Mann G (2018) Climate Leviathan: A Political Theory of Our Planetary Future. London \& New York: Verso.

Walker R (2017) Value and Nature: Rethinking Capitalist Exploitation and Expansion. Capitalism Nature Socialism 28(1): 53-61.

Webber JR (2017) The Last Day of Oppression, and the First Day of the Same: The Politics and Economics of the New Latin American Left. London: Pluto Press. 